\title{
Medullary thyroid cancer is associated with high serum vitamin $D$ level and polymorphism of vitamin D receptors
}

\author{
M RAMEZANI $^{1}$, M MAZANI $^{1}$, M TABATABAEI $^{2}$, A RAHIMIAN $^{3}$, \\ E MOSAFERI ${ }^{4}$ and M HEDAYATI ${ }^{5 *}$
}

\footnotetext{
${ }^{1}$ Department of Biochemistry, School of Medicine, Ardabil University of Medical Science, Ardabil, Iran

${ }^{2}$ Department of Immunology, School of Medicine, Shahid Beheshti University of Medical Sciences, Tehran, Iran

${ }^{3}$ Department of Medical Biochemistry, School of Medicine, Tehran University of Medical Sciences, Tehran, Iran

${ }^{4}$ Department of Immunology, School of Medicine, Tabriz University of Medical Sciences, Tabriz, Iran

${ }^{5}$ Cellular and Molecular Research Center, Research Institute for Endocrine Sciences, Shahid Beheshti University of Medical Sciences, Tehran, Iran
}

Received: January 26, 2019 • Accepted: January 28, 2020

Published online: April 10, 2020

(C) 2020 Akadémiai Kiadó, Budapest

\begin{abstract}
Background: Thyroid cancer is the most common endocrine malignancy. Studies have observed an anticancer effect for vitamin D and found that polymorphisms of vitamin D receptors can influence the prevalence of various cancers. The present study investigated the serum level of vitamin D and FokI, BsmI and Tru9I polymorphisms of vitamin D receptors. Methods: Forty patients with medullary thyroid cancer and 40 healthy controls were investigated. The genomic DNA of the subjects was extracted using saturated salt/proteinase K and investigated by PCR sequencing. Serum levels of vitamin D were evaluated by ELISA. The results were analyzed in SPSS and GraphPad Prism 5 software. Results: The genotypic and allelic frequencies of FokI and BsmI polymorphisms showed no significant differences between test and control groups. For Tru9I polymorphism, Tt genotype and $t$ allelic frequency in the test group were significantly different from those of the control group. Also, we found Tt genotype and
\end{abstract}

\footnotetext{
* Corresponding author. Cellular and Molecular Endocrine Research Center, Research Institute for Endocrine Sciences, Shahid Beheshti University of Medical Sciences, No. 24 Taleqani St, Velenjak, 1985717413, Tehran, Iran. Tel.: +98 912149 5939; Fax: +98 2122416264. E-mail: hedayati47@gmail.com
} 
$\mathrm{t}$ allelic frequency to be significantly associated with medullary thyroid cancer (MTC) type and the agressiveness of the disease. The average serum vitamin $\mathrm{D}$ level was $23.32 \mathrm{ng} / \mathrm{mL}$ and $18.95 \mathrm{ng} / \mathrm{mL}$ for patients and controls, respectively, and the difference between the two groups was statistically significant. Moreover, we found high serum vitamin D level to be associated with $t$ allelic frequency. Conclusions: Unexpectedly, the mean serum vitamin D level of the test group was significantly higher than that of the control group. Tru9I polymorphism was found to be significantly correlated with the prevalence of medullary thyroid carcinoma.

\section{KEYWORDS}

medullary thyroid carcinoma, vitamin $D$, vitamin $D$ receptor, polymorphism

\section{INTRODUCTION}

Thyroid cancer is the most common endocrine malignancy and accounts for $1-2 \%$ of all cancers. Epidemiological studies have reported a gradual increase in its overall incidence $[7,38]$. Thyroid cancers can be divided into four main subtypes including papillary, follicular, medullary and anaplastic $[8,11]$. Medullary thyroid cancer (MTC) is a rare form of thyroid cancer that accounts for $5-8 \%$ of all thyroid cancers. MTC originates from the parafollicular cells (C cells), whereas the other three types originate from follicular cells.

Several factors are involved in the growth of the thyroid gland. Thyroid-stimulating hormone (TSH) plays a major role in regulating growth and differentiation of thyroid cells. TSH stimulates the production of molecules involved in intracellular signal transduction, including cAMP [44], iodine uptake and cell growth [29]. The active form of vitamin D (1,25$(\mathrm{OH})_{2} \mathrm{D}_{3}$ ) binds to its receptor (VDR) using genomic and non-genomic mechanisms that inhibit the proliferative effect of TSH on thyroid cells. It is logical to propose that vitamin D plays a role in regulating thyroid gland cell proliferation. Binding of $1,25-(\mathrm{OH})_{2} \mathrm{D}_{3}$ to its receptor results in pleiotropic effects regulating calcium-phosphate metabolism, cell proliferation, differentiation, apoptosis, angiogenesis and metastasis. Vitamin $\mathrm{D}$ can thus be described as a very important agent in the anti-cancer response [3]. Accordingly, many studies have shown the anticancer effects of vitamin $\mathrm{D}$ on breast, prostate, colon and endocrine cancers [20].

In mammals, the expression of VDR is high in metabolic tissue, including the intestine, kidney, skin and thyroid gland. VDR is also expressed in high levels in tumor tissue [16]. This nuclear receptor function is affected by the presence of various genetic polymorphisms [26]. Several polymorphisms have been identified in the introns and exons of the VDR gene. These include Tru9I and BsmI on intron 8, FokI on exon 2 and TaqI on exon 9 [33]. FokI is located on the $5^{\prime}$ end and the other three polymorphisms are located on the $3^{\prime}$ end of the VDR gene [21].

Several studies have found a relationship between VDR gene polymorphisms and the risk of various cancers $[30,35,46]$. Also, we have previously demonstrated an association between RET gene polymorphisms and the risk of medullary thyroid cancer [18]. It could be concluded that changes in the vitamin D system can affect cancer progression. The current study evaluated serum levels of vitamin D and polymorphisms of the VDR gene in patients with MTC and compared the results with those of a healthy control group. 


\section{MATERIALS AND METHODS}

\section{Sample preparation}

The current study was carried out after obtaining prior permission from the Institutional Ethical Committee of the Cellular and Molecular Endocrinology Research Center at Shahid Beheshti University of Medical Sciences (No: IR.ARUMS.REC.93.66; dated: 28/2/2015). Written informed consent was received from all participants.

Forty patients with MTC including, 30 hereditary (29 FMTC and 1 MEN2B) and 10 sporadic cases were enrolled in the present study. The diagnoses were confirmed by pathological examination of thyroid tissue samples. Study controls were 40 age- and gender-matched normal healthy persons without a family history of thyroid carcinoma and with no autoimmune diseases, selected from the healthy staff members of Cellular and Molecular Endocrinology Research Center at Shahid Beheshti University of Medical Sciences.

About $10 \mathrm{~mL}$ of peripheral blood was obtained from each participant. Genomic DNA was extracted from nuclear cells of the peripheral blood using a standard salting-out procedure [31]. The concentration of the DNA sample was evaluated by UV spectrophotometry.

\section{Polymerase chain reaction and genotyping}

The polymerase chain reaction (PCR) assay was performed in a final volume of $35 \mu \mathrm{L}$ in premixed microtubes (Bioneer; South Korea) containing $1 \mathrm{U}$ Taq polymerase, dNTP (250 mM), Tris- $\mathrm{HCl}(10 \mathrm{mM}), \mathrm{KCl}(30 \mathrm{mM})$ and $\mathrm{MgCl}_{2}(1.5 \mathrm{mM})$. The following were added to each microtube: $1 \mu \mathrm{L}(5-10 \mathrm{pmol})$ of each amplification primer, $1 \mu \mathrm{L}(5-50 \mathrm{ng})$ of DNA and $32 \mu \mathrm{L}$ of sterile distilled water. PCR was carried out for 30 cycles (each cycle consisted of $35 \mathrm{~s}$ at $94{ }^{\circ} \mathrm{C}$ for denaturation, $1 \mathrm{~min}$ at $60.5{ }^{\circ} \mathrm{C}$ for annealing and $45 \mathrm{~s}$ at $72{ }^{\circ} \mathrm{C}$ for extension) with an initial denaturation at $95^{\circ} \mathrm{C}$ and final extension at $72^{\circ} \mathrm{C}$ for $10 \mathrm{~min}$. The $237 \mathrm{bp}$ fragment encompassing the FokI-rs 2228570 polymorphic site and the $339 \mathrm{bp}$ fragment encompassing the BsmI-rs 1544410 and Tru9I-rs757343 polymorphic sites were amplified using the specific primers (Table 1).

The purified PCR products were sequenced using forward primers by Bioneer (South Korea). Sequences were analyzed using Chromas Lite software (Technelysium) and verified against the sequence at the NCBI GenBank (National Center for Biotechnology Information) (Fig. 1).

\section{Measurement of 25-(OH) $\mathrm{D}_{3}$}

The concentration of $25-(\mathrm{OH}) \mathrm{D}_{3}$ was measured in the plasma of patients with MTC $(\mathrm{n}=40)$ and those in the control group $(n=40)$ using an Elisa kit according to instructions by the manufacturer (Calbiotec; USA).

Table 1. The primers used in VDR gene PCR

\begin{tabular}{ll}
\hline & Primer \\
\hline FokI & F:5-GATGCCAGCTGGCCCTGGCA-3 \\
& R:5-ATGGAAACACCTTGCTTCTT-3 \\
BsmI \& Tru9I $^{\mathrm{a}}$ & F:5-CAGAGTGTGCAGGCG-3 \\
& R:5-CCCTCTTTGGACCTCATCAC-3 \\
\hline
\end{tabular}

${ }^{\mathrm{a}} \mathrm{BsmI}$ and Tru9I are located on intron 8, therefore both could be amplified using a single pair of primers. 

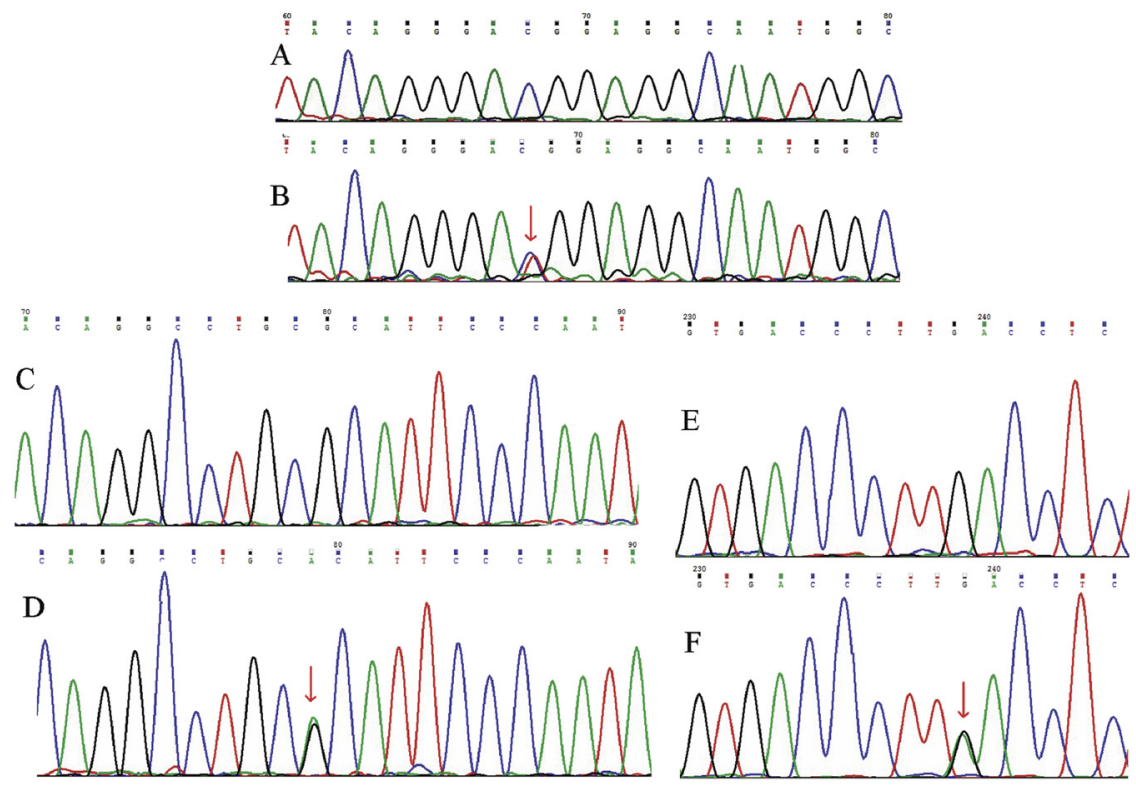

Fig. 1. VDR DNA sequencing results: (A) and (B) show results in exon 2. Peaks in (A) show the natural sequence of DNA and peaks in (B) show the expected heterozygous mutation (Fok-rs2228570 T > C). (C), (D), (E) and (F) show results in intron 8. (C) and (E) show natural sequence of DNA, respectively. (D) and

(F) show expected heterozygous mutations (BsmI-rs1544410 A $>$ G) and (Tru9I-rs757343 A > G), respectively

\section{Statistical analysis}

The association between MTC and genotypes was evaluated by the Chi-square test using SPSS (version 25). Fisher's Exact probability test was applied for analyzing the Tru9I polymorphism since the $t \mathrm{t}$ allelic frequency for control group was zero. The odds ratios and their $95 \%$ confidence intervals were estimated. The frequency distributions of the VDR polymorphisms were tested for HardyWeinberg equilibrium using the Chi-square test $(\mathrm{df}=1)$. A subgroup analysis was performed to evaluate the association between VDR polymorphism (Tru9I) and MTC type, pathological findings and gender of patients using Chi-square test. Also, Chi-square test was used to investigate the association between vitamin D level and gender of study subjects, VDR polymorphism (Tru9I), MTC type and pathological findings. Since the vitamin D levels were not normally distributed, the comparison of vitamin $\mathrm{D}$ between the test and control groups was estimated by the Mann-Whitney test using GraphPad Prism 5. A $P$-value of $<0.05$ was considered significant.

\section{RESULTS}

A total of 40 patients with MTC (mean age $36 \pm 7.57$ ) and 40 healthy controls (mean age $33 \pm$ 6.02) were included in this study. Analysis showed no statistically significant difference in mean age between the test and control groups. Distribution of patients by gender, age of disease onset and MTC type are shown in Table 2. 
Table 2. Baseline characteristics of patients/kindreds with medullary thyroid carcinoma indexed by age of disease onset and gender

\begin{tabular}{lclccccc}
\hline $\begin{array}{l}\text { Family/Patient } \\
\text { No. }\end{array}$ & Gender & $\begin{array}{c}\text { MTC } \\
\text { type }\end{array}$ & $\begin{array}{c}\text { Age of } \\
\text { onset }\end{array}$ & $\begin{array}{c}\text { Family/Patient } \\
\text { No. }\end{array}$ & Gender & $\begin{array}{c}\text { MTC } \\
\text { type }\end{array}$ & $\begin{array}{c}\text { Age of } \\
\text { onset }\end{array}$ \\
\hline 1 & M & FMTC & 17 & 21 & M & FMTC & 32 \\
2 & M & FMTC & 33 & 22 & F & FMTC & 26 \\
3 & M & Sporadic & 54 & 23 & F & FMTC & 28 \\
4 & M & Sporadic & 61 & 24 & F & FMTC & 43 \\
5 & M & Sporadic & 48 & 25 & F & MEN2B & 11 \\
6 & F & FMTC & 25 & 26 & F & FMTC & 32 \\
7 & F & FMTC & 46 & 27 & M & FMTC & 13 \\
8 & M & Sporadic & 57 & 28 & M & Sporadic & 47 \\
9 & F & FMTC & 35 & 29 & F & Sporadic & 50 \\
10 & M & FMTC & 48 & 30 & F & FMTC & 48 \\
11 & M & FMTC & 24 & $31 / 1$ & F & FMTC & 25 \\
12 & F & FMTC & 21 & $31 / 2$ & F & FMTC & 25 \\
13 & F & FMTC & 22 & $31 / 3$ & F & FMTC & 27 \\
14 & F & FMTC & 29 & 32 & F & FMTC & 37 \\
15 & F & FMTC & 37 & 33 & M & FMTC & 28 \\
16 & F & FMTC & 20 & 34 & F & FMTC & 38 \\
17 & M & FMTC & 37 & 35 & F & Sporadic & 61 \\
18 & F & FMTC & 36 & 36 & M & Sporadic & 32 \\
19 & F & Sporadic & 44 & 37 & F & Sporadic & 49 \\
20 & F & FMTC & 40 & 38 & F & FMTC & 34 \\
\hline
\end{tabular}

M: Male, F: Female, MTC: Medullary Thyroid Cancer, FMTC: Familial Medullary Thyroid Cancer, MEN2B: Multiple Endocrine Neoplasia 2B.

Table 3. Frequencies, $P$-values and Odds ratios of VDR polymorphisms in patients with medullary thyroid cancer and controls

\begin{tabular}{|c|c|c|c|c|c|}
\hline Polymorphism & Genotype & Carcinoma & Control & $P$-value & OR (95\% CI) \\
\hline \multirow[t]{3}{*}{ FokI } & FF & $1(2.5 \%)$ & $3(7.5 \%)$ & \multicolumn{2}{|c|}{ Reference Genotype } \\
\hline & Ff & $12(30.0 \%)$ & $12(30.0 \%)$ & 0.876 & $1.08(0.41-2.84)$ \\
\hline & $\mathrm{Ff}$ & $27(67.5 \%)$ & $25(62.5 \%)$ & 0.611 & $3.24(0.32-33.22)$ \\
\hline \multirow[t]{3}{*}{ BsmI } & $\mathrm{BB}$ & $23(57.5 \%)$ & $16(40.0 \%)$ & \multicolumn{2}{|c|}{ Reference Genotype } \\
\hline & $\mathrm{Bb}$ & $11(27.5 \%)$ & $20(50.0 \%)$ & 0.502 & $2.61(0.98-6.92)$ \\
\hline & $\mathrm{bb}$ & $6(15.0 \%)$ & $4(10.0 \%)$ & 0.953 & $0.96(0.23-3.95)$ \\
\hline \multirow[t]{3}{*}{ Tru9I } & $\mathrm{TT}$ & $21(52.5 \%)$ & $33(82.5 \%)$ & \multicolumn{2}{|c|}{ Reference Genotype } \\
\hline & $\mathrm{Tt}$ & $18(45.0 \%)$ & $7(17.5 \%)$ & 0.006 & $0.24(0.09-0.69)$ \\
\hline & $\mathrm{tt}$ & $1(2.5 \%)$ & $0(0 \%)$ & 1.00 & $(1.62-2.53)$ \\
\hline
\end{tabular}

OR: Odds Ratio; CI: Confidence Interval

\section{Genotypes}

All genotypes in the FokI and BsmI polymorphisms displayed similar frequencies in the test and control groups and no association between these polymorphisms and the risk of MTC was observed $(P>0.05)$. For the Tru9I polymorphism, the Tt genotype frequency in the test group 
Table 4. Allele frequencies, $P$-values and Odds ratios of VDR polymorphisms in patients with medullary thyroid cancer and controls

\begin{tabular}{|c|c|c|c|c|c|}
\hline Polymorphism & Allele & Carcinoma & Control & $P$-value & OR $(95 \% \mathrm{CI})$ \\
\hline \multirow[t]{2}{*}{ FokI } & $\mathrm{F}$ & $14(17.5 \%)$ & $18(22.5 \%)$ & \multicolumn{2}{|c|}{ Reference Allele } \\
\hline & $\mathrm{F}$ & $66(82.5 \%)$ & $62(77.5 \%)$ & 0.429 & $1.37(0.63-2.98)$ \\
\hline \multirow[t]{2}{*}{ BsmI } & B & $57(71.25 \%)$ & $52(65.0 \%)$ & \multicolumn{2}{|c|}{ Reference Allele } \\
\hline & $\mathrm{b}$ & $23(28.75 \%)$ & $28(35.0 \%)$ & 0.396 & $1.33(0.68-2.60)$ \\
\hline \multirow[t]{2}{*}{ Tru9I } & $\mathrm{T}$ & $60(75.0 \%)$ & $73(91.25 \%)$ & \multicolumn{2}{|c|}{ Reference Genotype } \\
\hline & $\mathrm{T}$ & $20(25.0 \%)$ & $7(8.75 \%)$ & 0.006 & $0.29(0.11-0.73)$ \\
\hline
\end{tabular}

OR: Odds Ratio; CI: Confidence Interval.

Table 5. Analysis of the association of Tru9I polymorphism with type of disease and gender of MTC patients

\begin{tabular}{|c|c|c|c|c|c|c|c|c|}
\hline \multirow[t]{13}{*}{ Related to } & \multicolumn{4}{|c|}{$\begin{array}{c}\text { Tru9I } \\
\text { Genotype } \\
\text { (for MTC } \\
\text { patients) }\end{array}$} & & & \multirow[t]{3}{*}{$\begin{array}{c}P \text { - } \\
\text { value }\end{array}$} & \multirow[t]{3}{*}{$\begin{array}{c}\text { OR } \\
(95 \% \mathrm{CI})\end{array}$} \\
\hline & \multirow[t]{4}{*}{ Gender } & & \multicolumn{2}{|r|}{ Male } & \multicolumn{2}{|r|}{ Female } & & \\
\hline & & & $\mathrm{N}$ & $\begin{array}{l}\% \text { (within } \\
\text { gender) }\end{array}$ & $\mathrm{N}$ & $\begin{array}{l}\% \text { (within } \\
\text { gender) }\end{array}$ & & \\
\hline & & TT & 8 & 57.1 & 13 & 50.0 & 0.242 & 0.556 \\
\hline & & $\mathrm{Tt}+\mathrm{tt}^{\mathrm{a}}$ & 6 & 42.9 & 13 & 50.0 & & $\begin{array}{c}(0.20- \\
1.49)\end{array}$ \\
\hline & \multirow[t]{4}{*}{ MTC type } & & \multicolumn{2}{|r|}{ FMTC } & \multicolumn{2}{|r|}{ Sporadic } & & \\
\hline & & & $\mathrm{N}$ & $\begin{array}{l}\% \text { (within } \\
\text { MTC type) }\end{array}$ & $\mathrm{N}$ & $\begin{array}{l}\% \text { (within } \\
\text { MTC type) }\end{array}$ & & \\
\hline & & $\mathrm{TT}$ & 13 & 43.3 & 8 & 80.0 & 0.044 & 5.23 \\
\hline & & $\mathrm{Tt}+\mathrm{tt}$ & 16 & 54.3 & 2 & 20.0 & & $\begin{array}{c}(0.947- \\
28.90)\end{array}$ \\
\hline & \multirow{4}{*}{$\begin{array}{l}\text { Pathological }^{\mathrm{b}} \\
\text { findings }\end{array}$} & & \multicolumn{2}{|c|}{ Aggressive } & \multicolumn{2}{|c|}{ Non-aggressive } & & \\
\hline & & & $\mathrm{N}$ & $\begin{array}{l}\% \text { (within } \\
\text { pathological } \\
\text { findings) }\end{array}$ & $\mathrm{N}$ & $\begin{array}{l}\% \text { (within } \\
\text { pathological } \\
\text { findings) }\end{array}$ & & \\
\hline & & $\mathrm{TT}$ & 3 & 21.4 & 18 & 69.2 & 0.004 & 0.121 \\
\hline & & $\mathrm{Tt}+\mathrm{tt}$ & 11 & 78.6 & 8 & 30.8 & & $\begin{array}{c}(0.026- \\
0.557)\end{array}$ \\
\hline
\end{tabular}

a There was only one patient with "tt" genotype in our population (a female with non-aggressive FMTC).

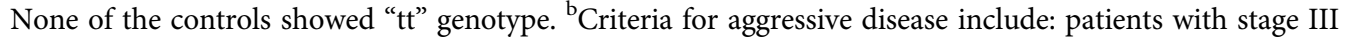
and IV (A, B or C) MTC or those patients who developed metastasis during the study period. 
Table 6. Analysis of the association of 25-(OH) D level with gender and Tru9I genotype in study subjects

\begin{tabular}{|c|c|c|c|c|c|c|c|c|c|c|c|c|c|c|}
\hline \multirow{3}{*}{\multicolumn{2}{|c|}{$\begin{array}{l}\text { Related } \\
\text { to }\end{array}$}} & \multirow{3}{*}{$\begin{array}{c}25(\mathrm{OH}) \\
\mathrm{D} \mathrm{level}^{\mathrm{a}}\end{array}$} & \multicolumn{6}{|c|}{ Controls } & \multicolumn{6}{|c|}{ Patients } \\
\hline & & & \multicolumn{2}{|r|}{ Male } & \multicolumn{2}{|r|}{ Female } & \multirow[t]{2}{*}{$P$} & \multirow{2}{*}{$\begin{array}{c}\text { OR } \\
(95 \% \mathrm{CI})\end{array}$} & \multicolumn{2}{|r|}{ Male } & \multicolumn{2}{|r|}{ Female } & \multirow[t]{2}{*}{$P$} & \multirow{2}{*}{$\begin{array}{c}\text { OR } \\
(95 \% \mathrm{CI})\end{array}$} \\
\hline & & & $\mathbf{N}$ & $\begin{array}{c}\% \text { (within } \\
\text { gender) }\end{array}$ & $\mathbf{N}$ & $\begin{array}{c}\% \text { (within } \\
\text { gender) }\end{array}$ & & & $\mathbf{n}$ & $\begin{array}{c}\% \text { (within } \\
\text { gender) }\end{array}$ & $\mathbf{N}$ & $\begin{array}{c}\% \text { (within } \\
\text { gender) }\end{array}$ & & \\
\hline & \multirow[t]{2}{*}{ Gender } & \multirow{2}{*}{$\begin{array}{c}\text { High } \\
(\geq 18.2 \\
\text { ng/mL }) \\
\text { Low } \\
(\leq 18.2 \\
\text { ng/mL })\end{array}$} & 11 & 61.1 & 6 & 27.3 & & \multirow[b]{2}{*}{$\begin{array}{c}4.19 \\
(1.10- \\
15.9)\end{array}$} & 10 & 71.4 & 11 & 42.3 & & \multirow[b]{2}{*}{$\begin{array}{c}3.40 \\
(0.84- \\
13.77)\end{array}$} \\
\hline & & & 7 & 38.9 & 16 & 72.3 & 0.031 & & 4 & 28.6 & 15 & 57.7 & 0.079 & \\
\hline & \multirow[t]{5}{*}{ Genotype } & \multirow{3}{*}{$\begin{array}{c}25(\mathrm{OH}) \\
\text { D level }\end{array}$} & \multicolumn{6}{|c|}{ Controls } & \multicolumn{6}{|c|}{ Patients } \\
\hline & & & \multicolumn{2}{|r|}{ TT } & \multicolumn{2}{|r|}{$\mathbf{T t}+\mathbf{t t}^{\mathrm{b}}$} & $P$ & \multirow{2}{*}{$\begin{array}{c}\text { OR } \\
(95 \% \mathrm{CI})\end{array}$} & & TT & \multicolumn{2}{|r|}{$\mathbf{T t}+\mathbf{t t}$} & \multirow[t]{2}{*}{$P$} & \multirow{2}{*}{$\begin{array}{c}\text { OR } \\
(95 \% \mathrm{CI})\end{array}$} \\
\hline & & & $\mathbf{N}$ & $\begin{array}{l}\% \text { (within } \\
\text { genotype) }\end{array}$ & $\mathbf{n}$ & $\begin{array}{l}\% \text { (within } \\
\text { genotype) }\end{array}$ & & & $\mathbf{n}$ & $\begin{array}{l}\% \text { (within } \\
\text { genotype) }\end{array}$ & $\mathbf{n}$ & $\begin{array}{l}\% \text { (within } \\
\text { genotype) }\end{array}$ & & \\
\hline & & High & 13 & 39.4 & 4 & 57.1 & & & 7 & 33.3 & 14 & 73.7 & & \\
\hline & & $\begin{array}{c}(\geq 18.2 \\
\mathrm{ng} / \mathrm{mL}) \\
\text { Low } \\
(\leq 18.2 \\
\mathrm{ng} / \mathrm{mL})\end{array}$ & 20 & 60.6 & 3 & 42.9 & 0.38 & $\begin{array}{c}2.05 \\
(0.39- \\
10.7)\end{array}$ & 14 & 66.7 & 5 & 26.3 & 0.011 & $\begin{array}{c}5.6(1.42- \\
21.94)\end{array}$ \\
\hline
\end{tabular}

${ }^{\mathrm{a}}$ Sampling was performed in winter and the cutoff point was determined based on the median vitamin $\mathrm{D}$ level of control samples.

bThere was only one patient with " $\mathrm{tt}$ " genotype in our population (a female with non-aggressive FMTC and a vitamin D level of more than $18.2 \mathrm{ng} /$ $\mathrm{ml})$. None of the controls showed " $\mathrm{tt}$ " genotype. 
was significantly different from control group $(P=0.006)$. The frequencies of FokI, BsmI and Tru9 genotypes, $P$-values and odds ratio $(\mathrm{OR})$ for the test and control groups are shown in Table 3.

The allelic frequencies in the polymorphisms in the test group were also determined. Except for Tru9I, there were no notable differences in allelic prevalence between groups (Table 4). For the Tru9I polymorphism, the frequency of the $t$ allele was significantly different between groups $(P=0.006)$. Statistical analysis showed that the frequency distribution of VDR polymorphisms in the study population attained Hardy-Weinberg equilibrium $(P>0.05)$.

\section{Subgroup analysis of Tru9l genotype}

The associations between the Tru9I polymorphism and gender, MTC type and disease aggressiveness were analyzed within the MTC patient group. According to the cross-table (Table 5), no significant association is observable between Tru9I genotype and the gender of patients. However, there is a strong association between disease aggressiveness and Tru9I genotype. According to our results the frequency of $\mathrm{Tt}$ and $\mathrm{tt}$ genotypes is significantly higher in patients with aggressive disease compared to patients with non-aggressive tumors $(P=0.004)$. It should be noted that the

Table 7. Analysis of the association of 25-(OH) D level with MTC type and disease aggressiveness

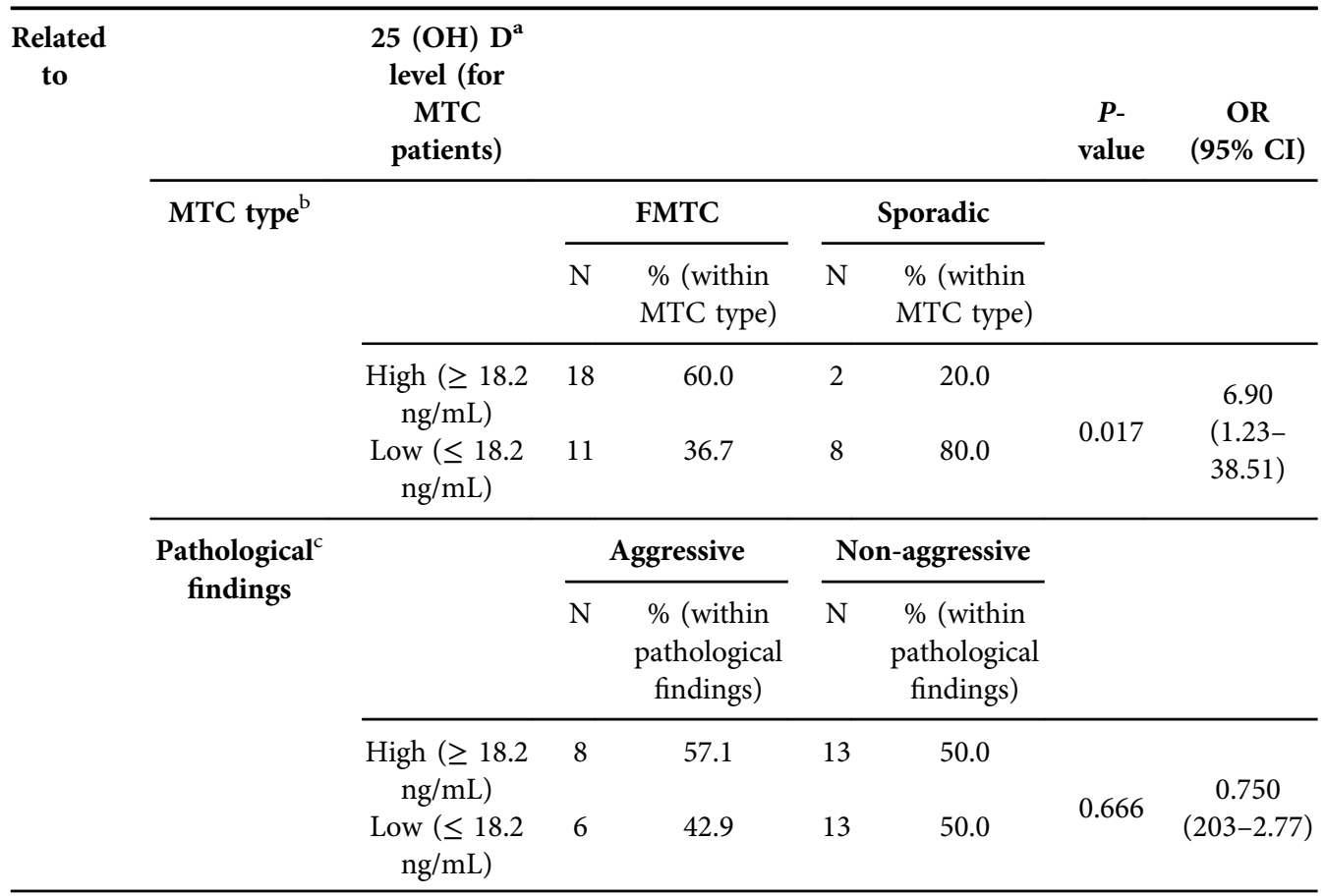

\footnotetext{
${ }^{a}$ Sampling was performed in winter and the cutoff point was determined based on the median vitamin D level of control samples. ${ }^{\mathrm{b}}$ There was only one patient with MEN2B disease in our population who was

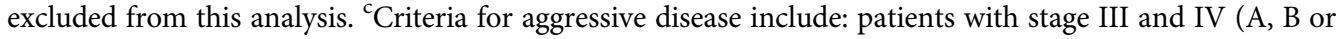
C) MTC or those patients who developed metastasis during the study period.
} 
majority of $\mathrm{t}$ alleles were present in Tt genotype, and there was only one patient with $\mathrm{tt}$ genotype who was a female with non-aggressive FMTC. Also, the Tt and tt genotypes were more frequent in patients with FMTC compared to those with sporadic tumors $(P=0.044)$.

\section{5-(OH) $D_{3}$ plasma level}

Plasma levels of 25-(OH) D were measured for the participants of both groups. A cutoff point was established to be used for categorizing study subjects into groups with high and low serum vitamin D levels. The cutoff point was determined based on the median of vitamin D levels obtained from control samples $(18.2 \mathrm{ng} / \mathrm{mL})$. Low vitamin D level $(\leq 18.2 \mathrm{ng} / \mathrm{mL})$ was more frequent in female controls $(P=0.031)$. Presumably, this is the result of clothing habits in the Iranian population. However, no significant difference in the distribution of high and low vitamin D levels was observable between male and female patients (Table 6). Our results show no significant association between serum vitamin $\mathrm{D}$ level and Tru9I polymorphism within the control group, whereas high vitamin $\mathrm{D}$ level $(\geq 18.2 \mathrm{ng} / \mathrm{mL})$ is more frequent in patients with $\mathrm{Tt}$

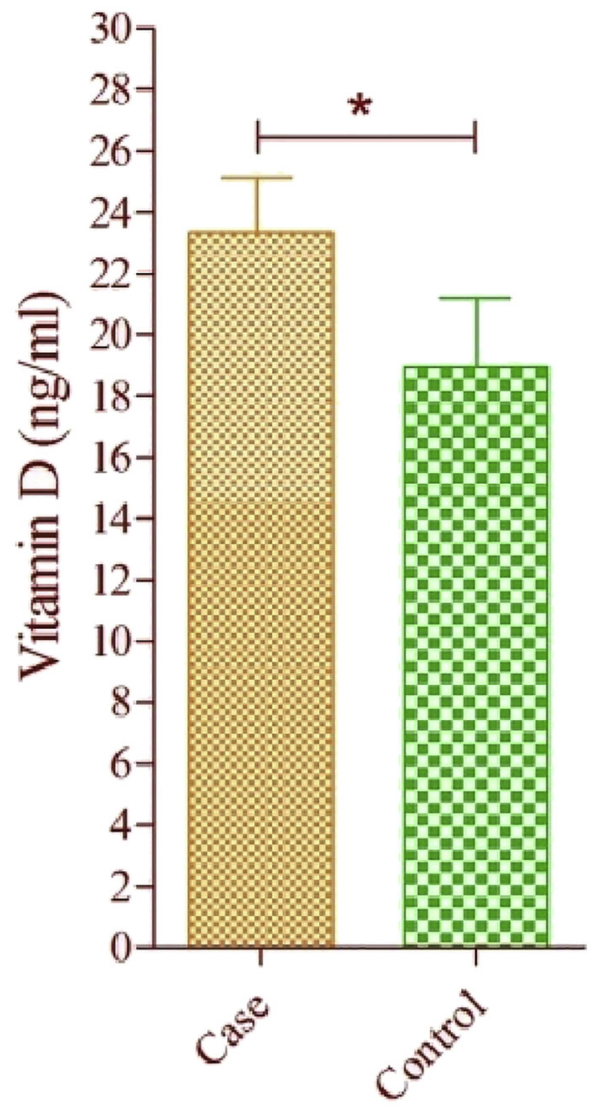

Fig. 2. Mean serum vitamin $\mathrm{D}$ level in test and control group $(P=0.02)$ 
and $t$ genotypes $(P=0.011)$ (Table 6). We also performed a subgroup analysis to evaluate the association of serum vitamin D level with MTC type and pathological findings (Table 7). According to our results there is no significant association between serum vitamin D level and disease aggressiveness, whereas the frequency of high vitamin D level in patients with FMTC is significantly higher than patients with sporadic MTC $(P=0.017)$. The average serum level of vitamin $\mathrm{D}$ was $23.32 \mathrm{ng} / \mathrm{mL}$ for the test group and $18.95 \mathrm{ng} / \mathrm{mL}$ for the control group, and this difference was statistically significant $(P=0.02)$ (Fig. 2).

\section{DISCUSSION}

Previous studies have shown an association between the serum levels of leptin, vaspin and medullary thyroid cancer $[17,19]$. To our knowledge, the present work is the first study evaluating the serum level of vitamin D and FokI, BsmI and Tru9I polymorphisms in patients with MTC compared to a healthy control group. Vitamin D has a role in different pathways, including those involved in anticancer activity, inhibition of cell proliferation and invasion, angiogenesis and metastasis of cancer cells $[20,26]$. Previous findings indicate that dysfunction of VDR or vitamin D deficiency can increase the risk of chronic diseases including cancer [47]. The antitumoral effect of vitamin D through its nuclear receptor (VDR) is well-documented. Previous findings indicate that increased local action of vitamin $\mathrm{D}$ is associated with differentiation, reduced proliferation and favorable prognosis in papillary thyroid carcinoma (PTC) [25]. Moreover, the antiproliferative effect of vitamin D on different thyroid cell lines - especially on papillary, follicular and anaplastic cells - has been investigated, mostly attributing an anti-proliferative activity to vitamin D analogs, which is most likely mediated through overexpression of the tumor suppressor p27 [5, 32]. However, the results by the studies concerning the antitumoral effect of vitamin $\mathrm{D}$ on $\mathrm{C}$ cells are controversial. There is almost consensus upon a decreasing effect of 1,25- $(\mathrm{OH}) 2 \mathrm{D} 3$ (calcitriol) on calcitonin secretion [36, 48]. However, the data about proliferative effect of vitamin $\mathrm{D}$ on $\mathrm{C}$ cells are very inconsistent. In contrast to antitumorigenic activity of vitamin $\mathrm{D}$ on most cancer cells, some findings indicate that vitamin $\mathrm{D}$ treatment results in enhanced cell proliferation in C cells (TT cell line) through increased gene expression of the c-myc oncogene $[2,6,48,49,50]$. These findings may partly explain the inconsistency of our results on vitamin $\mathrm{D}$ level with other studies. Based on the literature, the association between low vitamin $\mathrm{D}$ level and increased risk of most cancers is evident. However, for thyroid cancers, there are few studies evaluating the mentioned relationship. The data from clinical studies provide inconsistent information regarding the relationship between vitamin D status and risk of thyroid cancers [23, 27, 28, 41, 42, 45]. To our knowledge, there is only one isolated study reporting results consistent with our data on on vitamin status and MTC. This study introduces vitamin D supplementation as a risk factor for medullary thyroid cancer (OR: 1.8) [40]. Referring to our results, it is clear that although MTC patients exhibit higher vitamin D levels in comparison to control subjects, the mean vitamin $\mathrm{D}$ level is lower than the normal range for both MTC patients and the control group. It is very important to note that the vitamin D level in the Iranian population is significantly lower than what is established as the normal range by the world health authorities, and this is possibly due to the clothing, cultural and social norms.

VDR genes are located on the long arm of chromosome 12 and comprise 8 protein coding exons (exons 2-9) and 6 non-translated exons (exons a1-f1). Studies have shown that single 
nucleotide polymorphisms on exon 2 (FokI), intron 8 (BsmI and Tru9I) and exon 9 are associated with increased risk of ovarian [14], breast [43], colon [35], prostate [22], skin [9], follicular and papillary thyroid [37] cancers. The FokI polymorphism, located on the $5^{\prime}$ end, is a $\mathrm{T}$ to $\mathrm{C}$ substitution in the initial codon and increases the transcriptional activity of the VDR. The resulting difference of three amino acids in VDR length may affect the function of the protein. The polymorphisms located on the $3^{\prime}$ end of the VDR gene do not alter the amino acid sequence; however, it has been reported that the BsmI and Tru9I polymorphisms on the $3^{\prime}$ end may alter transcriptional activity and mRNA degradation [1].

In the present study, the genotypes and alleles of the FokI and BsmI polymorphisms showed no significant association with the risk of MTC. For the Tru9I polymorphism, the Tt genotype and $t$ allele frequencies in the test group were significantly different from the control group, indicating a considerable increased risk for MTC.

A similar study that evaluated vitamin D receptor polymorphism in patients with follicular and papillary thyroid cancer showed a significant association between FokI polymorphism and follicular cancer, but not papillary thyroid cancer. TaqI and BsmI polymorphisms showed no significant relationship [37]. Another similar study found no significant association between TaqI, Tru9I and BsmI polymorphisms with follicular and papillary thyroid cancers in the Iranian population; however, there was a significant difference in allele frequencies of the Tru9I polymorphisms between the test and control groups [15].

Significant associations between TaqI, Tru9I and BsmI polymorphisms and increased risk of melanoma, prostate, breast and ovarian cancers have been documented in previous studies [10, $24,46]$. Controversially, other studies have observed no significant association between these polymorphisms and prostate and ovarian cancer [4, 34].

Unexpectedly, in our study population, the plasma level of $25-(\mathrm{OH})$ D3 in the MTC group was significantly higher than in control subjects, whereas many studies reported an inverse relationship between sera levels of vitamin D and colon [13], breast [39], prostate [12] and follicular thyroid (37) cancer. Overall, the epidemiological evidence suggests limited and controversial results about this relationship [12, 39].

The results of the present study demonstrated that the Tru9I polymorphism of the VDR gene may commonly contribute to the risk of medullary thyroid cancer. Since, the present study is the first one focusing on patients diagnosed with MTC, and the sample size was relatively small due to the low rate of prevalence of this cancer, more studies with larger sample sizes are needed to confirm the results.

Conflict of interest: The authors declare that they have no conflict of interest.

\section{ACKNOWLEDGMENTS}

This study was funded by Ardabil University of Medical Sciences, Ardabil, Iran. We would like to thank all the members of Cellular and Molecular Endocrinology Research Center also the Department of Biochemistry in Ardabil University of Medical Sciences for their technical advice and assistance. 


\section{REFERENCES}

1. Arai H, Miyamoto K, Taketani Y, Yamamoto H, Iemori Y, Morita K, et al. A vitamin D receptor gene polymorphism in the translation initiation codon: effect on protein activity and relation to bone mineral density in Japanese women. J Bone Miner Res 1997; 12(6): 915-21, https://doi.org/10.1359/jbmr.1997.12.6.915.

2. Baier R, Grauer A, Lazaretti-Castro M, Ziegler R, Raue F. Differential effects of 1,25-dihydroxyvitamin D3 on cell proliferation and calcitonin gene expression. Endocrinology 1994; 135(5): 2006-11, https://doi.org/10. 1210/en.135.5.2006.

3. Carvalho IS, Goncalves CI, Almeida JT, Azevedo T, Martins T, Rodrigues FJ, et al. Association of Vitamin D Pathway Genetic Variation and Thyroid Cancer. Genes (Basel) 2019; 10(8): 572, https://doi.org/10.3390/ genes 10080572.

4. Clendenen TV, Arslan AA, Koenig KL, Enquist K, Wirgin I, Agren A, et al. Vitamin D receptor polymorphisms and risk of epithelial ovarian cancer. Cancer Lett 2008; 260(1-2): 209-15, https://doi.org/10.1016/ j.canlet.2007.11.002.

5. Clinckspoor I, Verlinden L, Overbergh L, Korch C, Bouillon R, Mathieu C, et al. 1,25-dihydroxyvitamin D3 and a superagonistic analog in combination with paclitaxel or suberoylanilide hydroxamic acid have potent antiproliferative effects on anaplastic thyroid cancer. J Steroid Biochem Mol Biol 2011; 124: 1-9, https://doi. org/10.1016/j.jsbmb.2010.12.008.

6. Cote GJ, Rogers DG, Huang ES, Gagel RF. The effect of 1,25-dihydroxyvitamin D3 treatment on calcitonin and calcitonin gene-related peptide mRNA levels in cultured human thyroid C-cells. Biochem Biophys Res Commun 1987; 149(1): 239-43, https://doi.org/10.1016/0006-291X(87)91630-5.

7. Doubi A, Al-Qannass A, Al-Angari SS, Al-Qahtani KH, Alessa M, Al-Dhahri S. Trends in thyroid carcinoma among thyroidectomy patients: a 12-year multicenter study. Ann Saudi Med 2019; 39(5): 345-9, https://doi. org/10.5144/0256-4947.2019.345.

8. Franssila K, Saxen E, Teppo L, Bjarnason O, Tulinius H, Normann T, et al. Incidence of different morphological types of thyroid cancer in the Nordic countries. Acta Pathol Microbiol Scand A 1981; 89(1): 49-55, https://doi.org/10.1111/j.1699-0463.1981.tb00186.x.

9. Gandini S, Raimondi S, Gnagnarella P, Dore JF, Maisonneuve P, Testori A. Vitamin D and skin cancer: a meta-analysis. Eur J Canc 2009; 45(4): 634-41, https://doi.org/10.1016/j.ejca.2008.10.003.

10. Gapska P, Scott RJ, Serrano-Fernandez P, Huzarski T, Byrski T, Kladny J, et al. Vitamin D receptor variants and breast cancer risk in the Polish population. Breast Canc Res Treat 2009; 115(3): 629-33, https://doi.org/ 10.1007/s10549-008-0107-1.

11. Ghazi AA, Bagheri M, Tabibi A, Sarvghadi F, Abdi H, Hedayati M, et al. Multiple endocrine neoplasia type 2A in an Iranian family: clinical and genetic studies. Arch Iran Med 2014; 17(5): 378-82, https://doi.org/0141705/ aim.0013.

12. Giovannucci E. Strengths and limitations of current epidemiologic studies: vitamin D as a modifier of colon and prostate cancer risk. Nutr Rev 2007; 65(8 Pt 2): S77-9, https://doi.org/10.1301/nr.2007.aug.S77-S79.

13. Gorham ED, Garland CF, Garland FC, Grant WB, Mohr SB, Lipkin M, et al. Optimal vitamin D status for colorectal cancer prevention: a quantitative meta analysis. Am J Prev Med 2007; 32(3): 210-6, https://doi.org/ 10.1016/j.amepre.2006.11.004.

14. Guo H, Guo J, Xie W, Yuan L, Sheng X. The role of vitamin D in ovarian cancer: epidemiology, molecular mechanism and prevention. J Ovarian Res 2018; 11(1): 71, https://doi.org/10.1186/s13048-018-0443-7.

15. Haghpanah V, Ghaffari SH, Rahimpou rP, Abbasi A, Saeedi M, Pak H, et al. Vitamin D receptor gene polymorphisms in patients with thyroid cancer. Gene Ther Mol Biol 2007; 11: 299-304. 
16. Haussler MR, Jurutka PW, Mizwicki M, Norman AW. Vitamin D receptor (VDR)-mediated actions of 1alpha,25(OH)(2)vitamin $\mathrm{D}(3)$ : genomic and non-genomic mechanisms. Best Pract Res Clin Endocrinol Metab 2011; 25(4): 543-59, https://doi.org/10.1016/j.beem.2011.05.010.

17. Hedayati M, Yaghmaei P, Pooyamanesh Z, Zarif Yeganeh M, Hoghooghi Rad L. Leptin: a correlated Peptide to papillary thyroid carcinoma? J Thyroid Res 2011; 2011: 832163, https://doi.org/10.4061/2011/832163.

18. Hedayati M, Zarif Yeganeh M, Sheikhol Eslami S, Rezghi Barez S, Hoghooghi Rad L, Azizi F. Predominant RET Germline Mutations in Exons 10, 11, and 16 in Iranian Patients with Hereditary Medullary Thyroid Carcinoma. J Thyroid Res 2011; 2011: 264248, https://doi.org/10.4061/2011/264248.

19. Jabbari S, Hedayati M, Yaghmaei P, Parivar K. Medullary Thyroid Carcinoma-Circulating Status of Vaspin and Retinol Binding Protein-4 in Iranian Patients. Asian Pac J Cancer Prev 2015; 16(15): 6507-12, https://doi. org/10.7314/apjcp.2015.16.15.6507.

20. Jeon SM, Shin EA. Exploring vitamin D metabolism and function in cancer. Exp Mol Med 2018; 50(4): 20, https://doi.org/10.1038/s12276-018-0038-9.

21. Jiao J, Li Y, Xu S, Wu J, Yue S, Liu L. Association of FokI, TaqI, BsmI and ApaI polymorphisms with diabetic retinopathy: a pooled analysis of case-control studies. Afr Health Sci 2018; 18(4): 891-9, https://doi.org/10. 4314/ahs.v18i4.7.

22. Jingwi EY, Abbas M, Ricks-Santi L, Winchester D, Beyene D, Day A, et al. Vitamin D receptor genetic polymorphisms are associated with PSA level, Gleason score and prostate cancer risk in African-American men. Anticancer Res 2015; 35(3): 1549-58.

23. Jonklaas J, Danielsen M, Wang H. A pilot study of serum selenium, vitamin D, and thyrotropin concentrations in patients with thyroid cancer. Thyroid 2013; 23(9): 1079-86, https://doi.org/10.1089/thy.2012.0548.

24. Kambale PR, Haldar D, Kabi BC, Kambale KP. Study of Vitamin D Receptor Gene Polymorphism (FokI, TaqI and ApaI) Among Prostate Cancer Patients in North India. J Clin Diagn Res 2017; 11(6): BC05-8, https://doi. org/10.7860/JCDR/2017/24290.9976.

25. Khadzkou K, Buchwald P, Westin G, Dralle H, Akerstrom G, Hellman P. 25-hydroxyvitamin D3 1alphahydroxylase and vitamin D receptor expression in papillary thyroid carcinoma. J Histochem Cytochem 2006; 54(3): 355-61, https://doi.org/10.1369/jhc.5A6734.2005.

26. Kurucu N, Sahin G, Sari N, Ceylaner S, Ilhan IE. Association of vitamin D receptor gene polymorphisms with osteosarcoma risk and prognosis. J Bone Oncol 2019; 14: 100208, https://doi.org/10.1016/j.jbo.2018.100208.

27. Laney N, Meza J, Lyden E, Erickson J, Treude K, Goldner W. The prevalence of vitamin D deficiency is similar between thyroid nodule and thyroid cancer patients. Int J Endocrinol Metab 2010; 2010: 805716, https://doi.org/10.1155/2010/805716.

28. Mack WJ, Preston-Martin S, Bernstein L, Qian D. Lifestyle and other risk factors for thyroid cancer in Los Angeles County females. Ann Epidemiol 2002; 12(6): 395-401, https://doi.org/10.1016/S1047-2797(01)00281-2.

29. Mehta RG, Mehta RR. Vitamin D and cancer. J Nutr Biochem 2002; 13(5): 252-64, https://doi.org/10.1016/ S0955-2863(02)00183-3.

30. Meng Li, Xinyu Liu, Na Liu, Tian Yang, Puyu Shi, Ruiqing He, et al. Association between Polymorphisms of Vitamin D Receptor and Lung Cancer Susceptibility: Evidence from an Updated Meta-analysis. J Canc 2019; 10(16): 3639-49, https://doi.org/10.7150/jca.33431.

31. Miller SA, Dykes DD, Polesky HF. A simple salting out procedure for extracting DNA from human nucleated cells. Nucleic Acids Res 1988; 16: 12-5, https://doi.org/10.1093/nar/16.3.1215.

32. Muscogiuri G, Tirabassi G, Bizzaro G, Orio F, Paschou SA, Vryonidou A, et al. Vitamin D and thyroid disease: to D or not to D? Eur J Clin Nutr 2015; 69(3): 291-6, https://doi.org/10.1038/ejcn.2014.265.

33. Ntais C, Polycarpou A, Ioannidis JP. Vitamin D receptor gene polymorphisms and risk of prostate cancer: a meta-analysis. Canc Epidemiol Biomarkers Prev 2003; 12(12): 1395-402. 
34. Oakley-Girvan I, Feldman D, Eccleshall TR, Gallagher RP, Wu AH, Kolonel LN, et al. Risk of early-onset prostate cancer in relation to germ line polymorphisms of the vitamin D receptor. Canc Epidemiol. Biomarkers Prev 2004; 13(8): 1325-30.

35. Pan Z, Chen M, Hu X, Wang H, Yang J, Zhang C, et al. Associations between VDR gene polymorphisms and colorectal cancer susceptibility: an updated meta-analysis based on 39 case-control studies. Oncotarget 2018; 9(16): 13068-76, https://doi.org/10.18632/oncotarget.23964.

36. Peleg S, Abruzzese RV, Cooper CW, Gagel RF. Down-regulation of calcitonin gene transcription by vitamin D requires two widely separated enhancer sequences. Mol Endocrinol 1993; 7(8): 999-1008, https://doi.org/10. 1210/mend.7.8.8232320.

37. Penna-Martinez M, Ramos-Lopez E, Stern J, Hinsch N, Hansmann ML, Selkinski I, et al. Vitamin D receptor polymorphisms in differentiated thyroid carcinoma. Thyroid 2009; 19(6): 623-8, https://doi.org/10.1089/thy. 2008.0388.

38. Rao SN, Cabanillas ME. Navigating Systemic Therapy in Advanced Thyroid Carcinoma: From Standard of Care to Personalized Therapy and Beyond. J Endocr Soc 2018; 2(10): 1109-30, https://doi.org/10.1210/js. 2018-00180.

39. Rohan T. Epidemiological studies of vitamin D and breast cancer. Nutr Rev 2007; 65(8 Pt 2): S80-3, https:// doi.org/nr.2007.aug.S80-S83.

40. Ron E, Kleinerman RA, Boice JD Jr., LiVolsi VA, Flannery JT, Fraumeni JF Jr. A population-based casecontrol study of thyroid cancer. J Natl Cancer Inst 1987; 79(1): 1-12, https://doi.org/10.1093/jnci/79.1.1.

41. Roskies M, Dolev Y, Caglar D, Hier MP, Mlynarek A, Majdan A, et al. Vitamin D deficiency as a potentially modifiable risk factor for thyroid cancer. J Otolaryngol Head Neck Surg 2012; 41: 160-3.

42. Sahin M, Ucan B, Ginis Z, Topaloglu O, Gungunes A, Bozkurt NC, et al. Vitamin D3 levels and insulin resistance in papillary thyroid cancer patients. Med Oncol 2013; 30(2): 589, https://doi.org/10.1007/s12032013-0589-5.

43. Shahabi A, Alipour M, Safiri H, Tavakol P, Alizadeh M, Milad Hashemi S, et al. Vitamin D receptor gene polymorphism: association with susceptibility to early-onset breast cancer in Iranian, BRCA1/2-mutation carrier and non-carrier patients. Pathol Oncol Res 2018; 24(3): 601-7, https://doi.org/10.1007/s12253-017-0281-8.

44. Shahid MA, Sharma S. Physiology, Thyroid Hormone USA: StatPearls, Treasure Island (FL); 2019.

45. Stepien T, Krupinski R, Sopinski J, Kuzdak K, Komorowski J, Lawnicka H, et al. Decreased 1-25 dihydroxyvitamin D3 concentration in peripheral blood serum of patients with thyroid cancer. Arch Med Res 2010; 41: 190-4, https://doi.org/10.1016/j.arcmed.2010.04.004.

46. Vasilovici AF, Grigore LE, Ungureanu L, Fechete O, Candrea E, Trifa AP, et al. Vitamin D receptor polymorphisms and melanoma. Oncol Lett 2019; 17(5): 4162-9, https://doi.org/10.3892/ol.2018.9733.

47. Wu S, Sun J. Vitamin D, vitamin D receptor, and macroautophagy in inflammation and infection. Discov Med 2011; 11(59): 325-35.

48. Zabel M, Dietel M. Calcitriol decreases calcitonin secretion from a human medullary carcinoma cell line via specific receptor action. Acta Endocrinol (Copenh) 1991; 125(3): 299-304, https://doi.org/10.1530/acta.0. 1250299.

49. Zabel M, Flig K, Gebarowska E, Surdyk-Zasada J. The effect of calcitriol and its analogues on proliferation and hormone expression in cultured cells of thyroid medullary carcinomas. Folia Morphol (Warsz) 2003; 62(4): 463-5.

50. Zabel M, Gebarowska E, Drag-Zalesinska M, Wysocka T. Effect of calcitriol on proliferation of TT cells and on expression of calcitonin gene. Folia Histochem Cytobiol 2002; 40(2): 187-8. 